\title{
High-resolution carbon isotope changes in the Permian-Triassic boundary interval, Chongqing, South China; implications for control and growth of earliest Triassic microbialites
}

\author{
Xinan $\mathrm{Mu}^{1}$, Steve Kershaw ${ }^{2 *}, \mathrm{Yue}^{3}{ }^{3}, \mathrm{Li} \mathrm{Guo}^{4}$, Yuping $\mathrm{Qi}^{3}$ and Alan Reynolds ${ }^{5}$ \\ ${ }^{1}$ State Key Laboratory of Palaeobiology and Stratigraphy, Nanjing Institute of Geology \\ and Palaeontology, CAS, 39 East Beijing Road, Nanjing 210008, China \\ ${ }^{2}$ Institute for the Environment, Brunel University, Uxbridge, Middlesex, UB8 3PH, UK \\ ${ }^{3}$ Laboratory of Micropalaeontology, Nanjing Institute of Geology and Palaeontology, \\ CAS, 39 East Beijing Road, Nanjing 210008, China \\ ${ }^{4}$ CASP, Department of Earth Sciences, University of Cambridge, Gravel Hill, 181a \\ Huntingdon Road, Cambridge, CB3 ODH, UK \\ ${ }^{5}$ Experimental Techniques Centre, Brunel University, Uxbridge, Middlesex, UB8 3PH, \\ UK \\ ${ }^{*}$ corresponding author
}

\begin{abstract}
High-resolution $\delta^{13} \mathrm{C}_{\text {CARB }}$ analysis of the Permian-Triassic boundary (PTB) interval at the Laolongdong section, Beibei, near the city of Chongqing, south China, encompasses the latest Permian and earliest Triassic major facies changes in the South China Block (SCB). Microbialites form a distinctive unit in the lowermost 190 $\mathrm{cm}$ above the top of the Changhsing Formation (latest Permian) at Laolongdong, comparable to a range of earliest Triassic sites in low latitudes in the Tethyan area. The data show that declining values of $\delta^{13} \mathrm{C}_{\mathrm{CARB}}$, well-known globally, began at the base of the microbialite. High positive values (+3-4 ppt) of $\delta^{13} \mathrm{C}_{\mathrm{CARB}}$ in the Late Permian are interpreted to indicate storage of ${ }^{12} \mathrm{C}$ in the deep waters of a stratified ocean, that was released during ocean overturn in the earliest Triassic, contributing to the distinctive fall in isotope values; this interpretation has been stated by other authors and is followed here. The $\delta^{13} \mathrm{C}_{\mathrm{CARB}}$ curve shows fluctuations within the microbialite unit, which are not reflected in the microbialite structure. Comparisons between microbialite branches and adjacent micritic sediment show little difference in $\delta^{13} \mathrm{C}_{\mathrm{CARB}}$, demonstrating that the microbialite grew in equilibrium with surrounding seawater. The Early Triassic microbialites are interpreted to be a response to upwelling of bicarbonate-rich poorly-oxygenated water in low latitudes of Tethys ocean, consistent with current ocean models for the PTB interval. However, the decline of $\delta^{13} \mathrm{C}_{\mathrm{CARB}}$ may be due to a combination of processes, including productivity collapse resulting from mass extinction, return of deep water to ocean surface,
\end{abstract}


X. Mu, S. Kershaw, Y. Li, L. Guo, Y. Qi, A. Reynolds "High-resolution carbon isotope changes in the Permian-Triassic boundary interval, Chongqing, South China; implications for control and growth of earliest Triassic microbialites” J. Asian Earth Sciences (2008)

Archive Version. Definitive version available at www.sciencedirect.com

oxidation of methane released from methane hydrate destabilisation, and atmospheric deterioration. Nevertheless, build-up of bicarbonate-rich anoxic deep waters may be expected as a result of the partial isolation of Tethys, due to continental geography; release of bicarbonate-rich deep water, by ocean upwelling, in the earliest Triassic may have been an inevitable consequence of this combination of circumstances.

Keywords: Permian-Triassic boundary, microbialite, anoxia, Tethys Ocean, carbon isotopes.

\section{Introduction}

A prominent decline of $\delta^{13} \mathrm{C}_{\text {CARB }}$ stable isotope values is well-known across the Permian-Triassic boundary (PTB) interval (e.g. Krull et al., 2004; Payne et al., 2004), attributed to several possible causes associated with the end-Permian mass extinction event (see Erwin, 2006 for review). This sharp change in carbon isotopes is superimposed on a steady decline through the Late Permian (e.g. Haas et al., 2006), and the prominent shift coincides with the PTB "event horizon", the sharp facies change marking the mass extinction. The event horizon occurs lower than the biostratigraphic Permian-Triassic boundary defined by the conodont Hindeodus parvus (see Krull et al. 2004). Microbialites are widespread either on, or a short distance above, the event horizon, including prominent examples in the South China Block (SCB). This paper describes and interprets detailed changes in $\delta^{13} \mathrm{C}_{\mathrm{CARB}}$ throughout a microbialite unit in the Laolongdong locality in the SCB, where PTB facies have been documented (Kershaw et al., 1999), and is the first account of carbon isotopes from these deposits. This paper is the full documentation of results presented by Mu et al. (2001). Comparison is made with other areas, and the formation of earliest Triassic microbialites discussed.

\section{Locality, geological setting and methods}

Laolongdong is located on the northern shelf of the SCB, near Chongqing (Fig.1), and lies in an area of gently folded Permian and Triassic rocks; beds dip at c.30 degrees, exposing the PTB interval across the hillside. The section logged from upper Permian to Lower Triassic encompasses a sequence of rocks including: the topmost Changhsing Formation sediments; the event horizon; its overlying microbialite; and the basal part of the subsequent Feixianguan Formation (Figs. 2 \& 3). Latest Permian conodonts occur in the upper part of the Changhsing Formation, and earliest Triassic conodonts were found in the upper part of the microbialite (Figs. 4 \& 5), including Hindeodus parvus, the first Triassic conodont. Kershaw et al. (2002) also found $H$. parvus near the top of the microbialite in nearby locations. However, Liu et al. (2006) reported $H$. parvus at the base of the microbialite in other sites; it is possible that the base of the microbialite, sharply overlying the Changhsing Formation, is indeed the PTB in this site, but this requires further precise stratigraphic work to confirm.

Therefore the biostratigraphic Permian-Triassic boundary here is not well-constrained at Laolongdong, so the key horizon in this analysis is the "event horizon" (Krull et al. 2004), identified by the base of the microbialite in this section. 
X. Mu, S. Kershaw, Y. Li, L. Guo, Y. Qi, A. Reynolds "High-resolution carbon isotope changes in the Permian-Triassic boundary interval, Chongqing, South China; implications for control and growth of earliest Triassic microbialites” J. Asian Earth Sciences (2008)

Archive Version. Definitive version available at www.sciencedirect.com

The microbialite is recrystallised to varying degrees, from partial to complete (Kershaw et al., 1999); no samples have been found with unaltered structure. Isotopes were measured primarily from micritic sediment between branches of microbialite; however, isotope data were also obtained from samples collected from the microbial fabric itself, in order to examine the relationship between the isotopes of the microbial structure and the directly adjacent sediment.

Samples were processed for $\delta^{13} \mathrm{C}_{\mathrm{CARB}}$ data in the Nanjing Institute using the procedure applied by Jin et al. (2000), as follows. 20-mg samples were extracted with a microdrill from micritic sediment of each sample of the microbialite unit. Great care was taken to exclude microbialite branches from the sediment samples. However, samples also were drilled to collect isotope information from the microbialite branches, for comparative purposes; the branches do contain micritic sediment in spaces within branches, but care was taken to avoid the sediment. Samples were reacted with $100 \% \mathrm{H}_{3} \mathrm{PO}_{4}$ at 25DegC for 8 hours. Samples were analysed in a Finnegan MAT251 mass spectrometer, for ${ }^{13} \mathrm{C}$ and ${ }^{18} \mathrm{O}$, using the Chinese national standard, an Ordovician carbonate from a site near Beijing (ref. Number GBW 04405: ${ }^{13} \mathrm{C}=0.57+/-0.03$ Pee Dee Belemnite (PDB); ${ }^{18} \mathrm{O}=-8.49+/-0.13$ PDB). Samples were examined in thin section and SEM for evidence of alteration that might affect the isotope data. Micritic sediments form the primary dataset, and are well-preserved, with no detectable recrystallisation.

\section{Results}

Fig. 3 illustrates the log measured at Laolongdong, together with $\delta^{13} \mathrm{C}_{\mathrm{CARB}}$ data. Fig. 4 tabulates the data, with reference numbers, and includes $\delta^{18} \mathrm{O}_{\text {CARB }}$. Fig. 5 shows examples of conodonts extracted from the samples, as indicated in Fig. 4. For the $\delta^{13} \mathrm{C}_{\mathrm{CARB}}$, there is a slight decline upwards through the Changhsing Formation from 3.229 ppt to $2.621 \mathrm{ppt}$, in keeping with the known long-term trend, followed by a sharp decline of values from the topmost Changhsing Formation into the microbialite. Therefore the prominent negative swing seems to start at the very base of the microbialite. Note that the curve dips to its lowest level in the middle of the microbialite, and rises a little at the top, into the overlying Feixianguan Formation, where there is a further drop in the final sample (Fig. 3B). The fluctuations of ${ }^{13} \mathrm{C}$ values in the microbialite therefore show sharp drop in ${ }^{13} \mathrm{C}$ values in the middle and the top of the microbialite, but Fig. 3A shows that, at a smaller scale of drawing, the most prominent decline is at the base.

Comparison between the $\delta^{13} \mathrm{C}_{\mathrm{CARB}}$ values of the microbial branches and the enclosing sediment shows that there is a small but inconsistent variation between the sediment and microbialite in each sample location. Carbon isotope measurements from micritic sediments from a range of studies are known to be robust (see review in Cramer et al. 2006). Although the branches are altered, they are enclosed in unaltered micrite, and the carbon isotope data show co-variance between the microbialite branch and sediment in co-eval samples (Fig. 3C); these facts provide confidence that $\delta^{13} \mathrm{C}_{\mathrm{CARB}}$ values of the microbialites have been retained. $\delta^{18} \mathrm{O}_{\mathrm{CARB}}$ data have not been analysed in this study, as a result of the known issues with 
X. Mu, S. Kershaw, Y. Li, L. Guo, Y. Qi, A. Reynolds "High-resolution carbon isotope changes in the Permian-Triassic boundary interval, Chongqing, South China; implications for control and growth of earliest Triassic microbialites” J. Asian Earth Sciences (2008)

Archive Version. Definitive version available at www.sciencedirect.com

oxygen isotopes in Palaeozoic rocks, in contrast to the robust nature of carbon isotopes (see review in Haas et al., 2006).

\section{Discussion}

4a. Carbon isotopes in the PTB transition

The high values of $\delta^{13} \mathrm{C}_{\text {CARB }}$ in the late Permian, and sharp decline of $\delta^{13} \mathrm{C}_{\text {CARB }}$ in the PTB interval, present a challenge of interpretation (see Erwin, 2006 for a review); here we consider five processes likely to have contributed to the negative excursion, within which the microbialites grew. 1) A common view is that sharp decline of $\delta^{13} \mathrm{C}_{\text {CARB }}$ indicates productivity collapse in response to mass extinction, as ${ }^{12} \mathrm{C}$ was no longer removed by photosynthesis from the shallow ocean, to be buried in sediments; however, even if productivity collapse did influence the isotope curve, a negative excursion to -3 ppt indicates other processes were occurring. 2) Release of methane from methane hydrates has also been linked with the negative change (e.g. Ryskin, 2003), but if this is true, then somewhere (even locally) there might be records of very light inorganic carbon in deposits, but these have not been recorded in the literature. Newton and Bottrell (2007) noted that methane may have $\delta^{13} \mathrm{C}_{\text {CARB }}$ values of $-60 \mathrm{ppt}$, but they also drew attention to the negative isotope excursion of the PalaeoceneEocene Thermal Maximum (PETM), which shows an overall negative change from approximately $0 \mathrm{ppt}$ to $-1 \mathrm{ppt}$; this small change, distributed globally, has been proposed as caused by methane release. Thus in the PTB transition, the much larger negative excursion may contain a component of light carbon released from destabilised methane hydrates. 3) Overturn of deep ocean waters that stored light carbon, discussed by many authors (e.g. Isozaki 1997; Knoll et al. 1996) can also explain the PTB negative carbon isotope excursion, because of the large capacity for oceans to store dissolved inorganic carbon. In this context, the PTB period also shows a significant sulphur isotope excursion, which is probably best explained by overturn of a deep anoxic ocean (Newton and Bottrell, 2007). 4) Palaeogeographic reconstruction (Fig. 6) shows that Tethys Ocean was surrounded on three sides by land of the Pangaea supercontinent. During the period of sea-level lowstand towards the end of the Permian it may be expected that weathering and erosion of crustal rocks and terrestrial organic matter would have resulted in an extended period of transport of large amounts of bicarbonate to the deep ocean, where it was stored. The organic component of this input would be isotopically light, supplementing ocean productivity of light carbon. Sephton et al. $(2002,2005)$ argued for a rapid input of large amounts of ${ }^{12} \mathrm{C}$ from terrestrial sources associated with volcanic disturbance of ecosystems, so the amount of organically-derived light carbon entering Tethys Ocean from the land is potentially a dominating factor. However, because the $\delta^{13} \mathrm{C}_{\mathrm{CARB}}$ levels in shelf limestones were high through the Late Permian, this suggests a long-term accumulation of light carbon stored in the deep ocean. 5) Carbon isotopes (and ocean oxidation states) have also been viewed in relation to productivity-limiting nutrients of nitrogen and phosphorus (e.g. Saltzman, 2005). Thus, greenhouse states with anoxic deep oceans undergo pervasive denitrification, so that nitrate becomes limiting for ecosystems; if this was the case for the Late Permian, then ocean overturn at the PTB would be expected to release nutrients into ocean upper waters. In this 
X. Mu, S. Kershaw, Y. Li, L. Guo, Y. Qi, A. Reynolds "High-resolution carbon isotope changes in the Permian-Triassic boundary interval, Chongqing, South China; implications for control and growth of earliest Triassic microbialites” J. Asian Earth Sciences (2008)

Archive Version. Definitive version available at www.sciencedirect.com

situation, phosphates, which are in much lower concentrations than nitrates in the oceans, might be expected to play a key role in controlling productivity, as suggested by Saltzman (2005) for oceans that had more vigorous circulation. The result of upwelling nutrients should have been rapid increase in productivity that might account for the microbialites in the absence of organisms that had just gone extinct. However, this suggested increased productivity in the Early Triassic oceans might have led to a positive isotope trend, counter to the established negative $\delta^{13} \mathrm{C}_{\text {CARB }}$ response at the PTB. Perhaps a positive trend was masked by negative-trending processes.

In summary, therefore, there are several processes that may combine to explain the negative carbon isotope excursion. Because of the anoxic marine facies recorded in many Early Triassic shelf settings, we consider ocean overturn was the principal driving force for the excursion, providing the bulk of the bicarbonate for precipitation of microbial and inorganic carbonate on the shallow sea floor.

\section{4b. Carbon isotopes, marine oxygenation and earliest Triassic microbialites}

Following arguments arising from study of sulphur isotopes mentioned above, there is ample evidence that many earliest Triassic microbialites grew in a regime of poor oxygenation in shallow waters (Wignall and Twitchett, 2002), applicable to Laolongdong, but there are also sites with poor oxygenation (Wignall and Twitchett, 2002) that lack microbialites. Furthermore, Kozur (2007, p. 173) gave a general statement to note that ostracods, of types typical of oxygenated water, occur in the Abadeh section, Iran. Stromatolites are present in open-marine environments in earliest Triassic deposits of Abadeh (see Kershaw et al. 2007 for discussion), therefore oxygenation is not necessarily causally linked to earliest Triassic microbialites. Arguments presented by Riding (2005) and Riding and Liang (2005), that microbialites in the geological record are favoured by conditions of bicarbonate supersaturation, may be consistent with their occurrence in the earliest Triassic. Such arguments involve assessment of ocean processes, discussed below.

Fluctuation of $\delta^{13} \mathrm{C}_{\text {CARB }}$ found in this study within the microbialite unit is not reflected in either the physical appearance of the facies nor the microbialite architecture. Although facies changes at the top of the microbialite are readily recognisable in the field, the isotopes from Laolongdong do not register these changes. Such information reinforces our view that activity within the oceans, indicated by isotope fluctuations, was not the only control on growth of microbialites. Fluctuations in $\delta^{13} \mathrm{C}_{\text {CARB }}$ through the PTB interval were reported from microbialites of the southern SCB sites in Nanpanjiang Basin (Krull et al., 2004, Figs. 6B and 7B). However separate localities within Nanpianjiang Basin, $200 \mathrm{~km}$ apart, show different fluctuations (see Krull et al., 2004, Figs. 6B and 7B) within the negative swing of the isotope curve. The implications of fluctuations in the curve (Fig. 3B) are not clear, but at present cannot be linked to physical changes in the sedimentary deposits.

Carbon isotope data in Fig. $3 \mathrm{C}$ are evidence that sediment enclosing the microbialite structure was contemporaneous with the growth of the microbialite branches. These results support the suggestion by Kershaw et al. $(1999,2002)$ that microbialite branches protruded a short distance above the enclosing sediment, keeping pace with sedimentation as the microbialite branches grew. 
X. Mu, S. Kershaw, Y. Li, L. Guo, Y. Qi, A. Reynolds "High-resolution carbon isotope changes in the Permian-Triassic boundary interval, Chongqing, South China; implications for control and growth of earliest Triassic microbialites” J. Asian Earth Sciences (2008)

Archive Version. Definitive version available at www.sciencedirect.com

4c. Carbon isotopes, microbialites and Tethys Ocean

The central Tethyan deposits seem to contain the most significant microbialites, in terms of their distribution and abundance. In particular, Turkey (Baud et al., 2005) and Iran (Heydari et al. 2000) have important microbial deposits, located in central Tethyan positions during the PTB interval (Fig. 6). Other earliest Triassic microbialites occur in a range of sites around the Tethyan ocean margin, some high latitude sites, and also in oceanic platforms in western Panthalassa (now Japan); see Flügel (2002, p. 400) for a compendium. Microbialites have also been reported in Nevada and Utah, in low latitude western Pangaea (Pruss et al., 2006); however those microbialites are late Early Triassic, and it is notable that identification of the PTB in western Pangaea is an unresolved issue (Alvarez and O'Connor, 2002). Consequently, current evidence does not include earliest Triassic microbialites in western Pangaea, and remains a gap in the dataset.

Within Tethys, it is evident that the contemporaneous position of the SCB may be related to ocean models. Two published models are particularly relevant in the interpretation of isotopic change in the microbialites. Kidder and Worsley (2004) interpreted circulation patterns in Tethys Ocean, and in keeping with modern ocean processes, interpreted oceanic upwelling to have occurred along continental margins and in equatorial areas of ocean gyre divergence (Fig. 6). Thus the location of the SCB directly coincides with the region of upwelling. Furthermore, Kiehl and Shields (2005) modelled Tethys Ocean to have developed an extreme state of stratification, and it is clear that the almost enclosed geography of Tethys contributed to slow circulation and development of a stratified ocean mass. High $\delta^{13} \mathrm{C}_{\mathrm{CARB}}$ values through the Late Permian coincide with a time when carbonate platforms were well developed in the region. This coincidence supports the model recently proposed by Cramer et al. (2006) that burial of ${ }^{12} \mathrm{C}$ in the deep ocean allows the relatively higher remaining levels of ${ }^{13} \mathrm{C}$ to enter the shallow marine carbonate system; this arrangement would work during a stratified ocean, with sluggish circulation that prevented return of ${ }^{12} \mathrm{C}$ to surface waters.

Given that stratified oceans are modelled to have reduced circulation strength, then accumulation of oxygen-poor bicarbonate-rich water in deep Tethys is possible, and maybe even likely (Kiehl and Shields, 2005). In anoxic waters, sulphate reduction is likely to lead to increased concentrations of bicarbonate (Kempe 1990). Thus the elevated $\delta^{13} C_{\text {CARB }}$ values through the late Permian (Fig. 3) could reflect a stratified ocean where isotopically light carbon was stored in the deep ocean in stagnant conditions (Isozaki, 1997; Wignall and Twitchett, 2002), particularly in Tethys. If the ocean overturned, then return (by upwelling) of isotopically light carbon to surface waters could dominate the observed fall in $\delta^{13} \mathrm{C}_{\text {CARB }}$.

Kump (2005) proposed that upwelling of $\mathrm{H}_{2} \mathrm{~S}$ from the deep ocean in Early Triassic time created anoxia at the surface. If upwelling occurred principally in equatorial zones, then this is consistent with the location of the SCB (and Iran and Turkey) in eastern central Tethys, where modelling by Kidder and Worsley (2004) indicates that upwelling would be focused (Fig. 5). The work by Kump (2005) also potentially solves the problem of what mechanism led to ocean overturn. In a slowly 
X. Mu, S. Kershaw, Y. Li, L. Guo, Y. Qi, A. Reynolds "High-resolution carbon isotope changes in the Permian-Triassic boundary interval, Chongqing, South China; implications for control and growth of earliest Triassic microbialites” J. Asian Earth Sciences (2008)

Archive Version. Definitive version available at www.sciencedirect.com

circulating stratified ocean under a warm climate, conduits of upwelling may have been the routes of anoxic waters to the surface.

Therefore, in general terms, growth of earliest Triassic microbialites may have been stimulated by a combination of supersaturation driven by upwelled bicarbonaterich deep waters, and low oxygen shallow ocean conditions (Kershaw et al. 2007). Although oxygen-poor conditions were widespread (Wignall and Twitchett, 2002), microbialites did not form everywhere, probably because in those places the supersaturation was not high enough. Ostracod data from Laolongdong (CrasquinSoleau and Kershaw 2005) show low oxygen levels within the microbialite, consistent with the interpretation by Kershaw et al. (2007). However, given the ostracod data in Iran mentioned above (Kozur, 2007), low oxygen settings appear to be of secondary importance in the formation of microbialites. Thus the primary control on microbialite growth was probably bicarbonate supersaturation, supporting the views of Riding (2005) and Riding and Liang (2005).

The argument presented in the preceding paragraphs depends to some extent on the accuracy of palaeogeographic reconstruction. Nevertheless, even if Iran, Turkey and SCB were in different positions from those in Golonka's (2002) reconstruction used in this paper, their low latitude settings would have promoted the accumulation of microbialites in this oceanic overturn model. Low latitude western Pangaea is another candidate to receive bicarbonate-rich water by upwelling, but as mentioned above, problems remain with recognition of basal Triassic facies. It is interesting to note that the simulation by Kiehl and Shields (2005) predicts upwelling of deep cold waters in western Pangaea. Therefore earliest Triassic microbialites might be found there in future work; however, if they are not found, then their absence might be due to lack of sufficient bicarbonate saturation in the open circulating waters of eastern Panthalassa.

\section{Conclusions}

1. This high-resolution study demonstrates that the widespread sharp decline in $\delta^{13} \mathrm{C}_{\text {CARB }}$ in the earliest Triassic is also recorded in the distinctive microbialites of the northern marine shelf of the South China Block.

2. Fluctuations of $\delta^{13} \mathrm{C}_{\mathrm{CARB}}$, recognised in both the microbialite branches, and the adjacent sediment, is not accompanied by changes in the microbialite architecture or microstructure. Therefore, although the microbialite is interpreted to have grown in conditions of low oxygen and high bicarbonate concentrations, microbialite growth appears not sensitive to minor shifts in $\delta^{13} \mathrm{C}_{\text {CARB }}$.

3. The similarity in $\delta^{13} \mathrm{C}_{\mathrm{CARB}}$ between microbialite branches and adjacent sediment indicates that the sediment was deposited contemporaneous with microbialite branches, layer by layer. This scenario reinforces previous interpretations that only the top of microbialite structure was exposed above the sea floor at any one time.

4. Correspondence of fluctuations in $\delta^{13} \mathrm{C}_{\mathrm{CARB}}$ between microbial structure and sediment also shows the microbial branches grew in equilibrium with seawater. 
X. Mu, S. Kershaw, Y. Li, L. Guo, Y. Qi, A. Reynolds "High-resolution carbon isotope changes in the Permian-Triassic boundary interval, Chongqing, South China; implications for control and growth of earliest Triassic microbialites” J. Asian Earth Sciences (2008)

Archive Version. Definitive version available at www.sciencedirect.com

5. Laolongdong site is in a region of focused earliest Triassic microbialite growth, in eastern Tethys, where upwelling of low-oxygen bicarbonate-rich water stimulated its development for a short time in the earliest Triassic.

\section{Acknowledgments}

We thank Professor Lunde Luo, Southwest Normal Unversity, for the assistance with fieldwork; Mr. Xiaomin Chen for the analysis of the stable isotope. This work is supported by the grant from NNSF40572069, CAS and LPS. SK thanks Brunel University for facilities. Careful reviews by Prof Shuzhong Shen and Brad Cramer are gratefully acknowledged.

\section{References}

Alvarez, W. and O'Connor, D. 2002. Permian-Triassic boundary in the southwestern United States: hiatus or continuity? In: Koerberl, C. and MacLeod, K.G., eds., Catastrophic events and mass extinctions: impacts and beyond. Geological Society of America Special Paper 356, 385-393.

Baud, A., Richoz, S. and Marcoux, J. 2005. Calcimicrobial cap rocks from the basal Triassic units: western Taurus occurrences (SW Turkey). Comptes Rendus Paleovol, 4, 569-582.

Cramer, B.D., Saltzman, M.R. and Kleffner, M. (2006). Spatial and temporal variability in organic carbon burial during global positive carbon isotope excursions: new insight from high resolution $\delta^{13} \mathrm{C}_{\mathrm{CARB}}$ stratigraphy from the type area of the Niagaran (Silurian) Provincial Series. Stratigraphy, 2 (4), 1-14.

Cramer, B.D. and Saltzman, M.R. (2007). Fluctuations in epeiric sea carbonate production during Silurian positive carbon isotope excursions; a review of proposed palaeoceanographic models. Palaeogeography, Palaeoclimatology, Palaeoecology, 245, 37-45.

Erwin, D.H. 2006. Extinction. Princeton University Press. 296pp.

Flügel, E. 2002. Triassic Reef Patterns. In: Kiessling, W., Flügel, E., Golonka, J., eds., Phanerozoic reef patterns. SEPM Special Publication 72: 391-463.

Golonka, J. 2002. Plate-tectonic maps of the Phanerozoic. In: Kiessling, W., Flügel, E. and Golonka, J., eds., Phanerozoic Reef Patterns. SEPM Special Publication No. 72, 21-76.

Heydari, E., Hassandzadeh, J. and Wade, W.J. 2000. Geochemistry of central Tethyan Upper Permian and Lower Triassic strata, Abadeh region, Iran. Sedimentary Geology, 137, 85-99.

Haas, J., Demény, A., Hips, K. and Vennemann, T.W., 2006. Carbon isotope excursions and microfacies changes in marine Permian-Triassic boundary sections in Hungary. Palaeogeography, Palaeoclimatology, Palaeoecology, 237: 160-181.

Isozaki, Y. 1997. Permo-Triassic superanoxia and stratified superocean: records from the lost deep sea. Science, 276, 235-238.

Jin, Y.G., Wang, Y., Wang, W., Shang, Q.H., Cao, C.Q. and Erwin, D.H. 2000.

Pattern of marine mass extinction near the Permian-Triassic boundary in South 
X. Mu, S. Kershaw, Y. Li, L. Guo, Y. Qi, A. Reynolds "High-resolution carbon isotope changes in the Permian-Triassic boundary interval, Chongqing, South China; implications for control and growth of earliest Triassic microbialites” J. Asian Earth Sciences (2008) Archive Version. Definitive version available at www.sciencedirect.com

China. Science, 289 (5478), 432-436.

Kempe, S., 1990. Alkalinity: the link between anaerobic basins and shallow water carbonates? Naturwissenschaften, 77, 426-427.

Kershaw, S., Zhang, T.S. and Lan, G.Z. 1999. A ?microbialite crust at the PermianTriassic boundary in south China, and its palaeoenvironmental significance. Palaeogeography, Palaeoclimatology, Palaeoecology, 146, 1-18.

Kershaw, S., Guo, L., Swift, A. and Fan, J.S. 2002. ?Microbialites in the PermianTriassic boundary interval in central China: structure, age and distribution. Facies, 47, 83-90.

Kershaw, S., Li, Y., Crasquin-Soleau, S., Feng, Q., Mu, X., Collin, P-Y, Reynolds, A. and Guo, L. 2007. Earliest Triassic Microbialites in the South China Block and other areas: controls on their growth and distribution. Facies, 53 (3), 409-425.

Kidder, D. L. and Worsley, T.R. 2004. Causes and consequences of extreme PermoTriassic warming to globally equable climate and relation to the Permo-Triassic extinction and recovery. Palaeogeography, Palaeoclimatology, Palaeoecology, 203, 207-237.

Kiehl, J.T. and Shields, C.A. 2005. Climate simulation of the latest Permian: implications for mass extinction. Geology, 33, 757-760.

Knoll, A.H., Bambach, R.K., Canfield, D.E. and Grotzinger, J.P., 1996. Comparative Earth History and Late Permian mass extinction. Science, 273: 452-457.

Kozur, H.W. 2007. Biostratigraphy and event stratigraphy in Iran around the PermianTriassic Boundary (PTB): implications for the causes of the PTB biotic crisis. Global and Planetary Change, 55, 155-176.

Krull, E.S., Lehrmann, D.J., Druke, D., Kessel, B., Yu, Y.Y. and Li, R.X. 2004. Stable carbon isotope stratigraphy across the Permian-Triassic boundary in shallow marine carbonate platforms, Nanpanjiang Basin, South China. Palaeogeography, Palaeoclimatology, Palaeoecology, 204, 297-315.

Kump, L. R. 2005. Massive release of hydrogen sulphide to the surface ocean and atmosphere during intervals of ocean anoxia. Geology, 33, 397-400.

Liu, J.B., Ezaki, Y. and Yang, S. 2006. High-resolution environmental reconstruction of the aftermath of the end-Permian mass extinction: evidence from microbialite successions in South China. In: Yang, Q., Wang, Y.D. and Weldon, E.A. Ancient life and modern approaches; abstracts of the Second International Palaeontological Congress, Beijing, 17-21 June 2006. 208-209.

Mu, X.N., Guo, L., Kershaw, S. and Qi, Y.P. 2001. The microbialite crust at PermianTriassic boundary interval in E. Sichuan, China. In: Bucur, I. And Tantau, I. (eds). $4^{\text {th }}$ Regional Symposium of I.F.A.A. , August 29 - September 5, 2001, ClujNapoca, Romania, Abstracts, 38-39.

Newton, R. and Bottrell, S. 2007. Stable isotopes of carbon and sulphur as indicators of evironmental change: past and present. Journal of the Geological Society, 164, 691-708.

Payne, J., Lehrmann, D.J., Wei, J.Y., Orchard, M.J., Schrag, D.P. and Knoll, A.H. 2004. Large perturbations of the carbon cycle during recovery from the endPermian extinction. Science, 305, 506-509. 
Pruss, S.B., Bottjer, D.J., Corsetti, F.A., Baud, A. 2006. A global marine sedimentary response to the end-Permian mass extinction: examples from southern Turkey and the western United States. Earth Science Reviews, 78: 193-206.

Riding, R. 2005. Phanerozoic reefal microbial carbonate abundance: comparisons with metazoan diversity, mass extinction events, and seawater saturation state. Revista Espanola de Micropaleontologia, 37, 23-39.

Riding, R. and Liang, L.Y. 2005. Geobiology of microbial carbonates: metazoan and seawater saturation state influences on secular trends during the Phanerozoic. Palaeogeography, Palaeoclimatology, Palaeoecology, 219, 101-115.

Ryskin, G. 2003. Methane-driven oceanic eruptions and mass extinctions. Geology, 31, 741-744.

Saltzman, M.R. 2005. Phosphorus, nitrogen, and the redox evolution of the Palaeozoic oceans. Geology, 33, 573-576.

Sephton, M.A., Looy, C.V., Veefkind, R.J., Brinkhuis, H., De Leeuw, J.W. and Visscher, H. 2002. Synchronous record of $\delta^{13} \mathrm{C}$ shifts in the oceans and atmosphere at the end of the Permian. In: Koerberl, C. and MacLeod, K.G., eds., Catastrophic events and mass extinctions: impacts and beyond. Geological Society of America Special Paper 356, 455-462.

Sephton, M.A., Looy, C.V., Brinkhuis, H., Wignall, P.B., de Leeuw, J.W. and Visscher, H. 2005. Catastrophic soil erosion during the end-Permian biotic crisis. Geology, 33, 941-944.

Wignall, P.B. and Twitchett, R.J. 2002. Extent, duration and nature of the PermianTriassic superanoxic event. In: Koerberl, C. and MacLeod, K.G., eds., Catastrophic events and mass extinctions: impacts and beyond. Geological Society of America Special Paper 356, 395-413. 


\section{Figure captions}

Fig. 1. Location of Laolongdong and general geology of this area of Chongqing and Sichuan Province.

Fig. 2. Field photographs of the microbialite at Laolongdong. A. shows the area of the top of the microbialite, with arrows to show its upper boundary; lens cap $(5 \mathrm{~cm}$ diameter) at top edge of photo, centre right. B. Enlarged view of the microbialite top, showing prominent branched structure and slightly eroded top. See Kershaw et al. (1999) for more field and thin section photos.

Fig.3. A. Graph of $\delta^{13} \mathrm{C}_{\mathrm{CARB}}$ at Laolongdong, showing the sustained strongly positive values in the lower $20 \mathrm{~m}$, and sudden fall at the PTB event horizon. CF= Changhsing Fm (reef limestones and grainstones); FF= Feixianguan Fm (packstones and wackestones). The horizontal-ruled symbol in the upper part of $A$ is a simplification of the details in B. B. Detailed changes of ${ }^{813} \mathrm{C}_{\mathrm{CARB}}$ through the microbialite, with close sample spacing. Numbered samples are from the microbialite. Log of the Laolongdong section. 1= Changhsing Fm limestones; $2=$ Microbialite layers; $3=$ thinbedded micritic limestone; $4=$ argillaceous thin-bedded micritic limestone; $5=$ shaly micritic limestone. C. Comparison of ${ }^{813} \mathrm{C}_{\mathrm{CARB}}$ between microbialite branches and the immediately adjacent micritic sediment, in all microbialite samples, except $\mathrm{T} 7$, which contained only sediment.

Fig. 4. $\delta^{13} \mathrm{C}_{\mathrm{CARB}}$ and $\delta^{18} \mathrm{O}_{\mathrm{CARB}}$ isotope data, showing reference numbers and log heights; data are plotted in Fig. 3. Note 1: Hindeodus parvus (20 specimens); Hindeodus latidentatus (3 specimens); Hindeodus typicalis (2 specimens); H. sp (10 specimens). Note 2: Hindeodus parvus (1 specimens); Hindeodus latidentatus (2 specimens). Note 3: top of Changhsing Fm; Clarkina Changhsingensis (1 specimen); Clarkina deflecta (1 specimen); C. sp (5 specimens); Fish teeth, gen. et sp. indet. (2 specimens).

Fig. 5. SEM photomicrographs of conodonts extracted from samples in Laolongdong, as shown in Fig. 4. 1: Clarkina deflecta; 2: Hindeodus parvus; 3: $H$. typicalis; 4: $H$. latidentatus. Scale bar $0.2 \mathrm{~mm}$. Note that in 1 , the illustrated specimen represents a form genus that has a wide range in the Upper Permian, and identifies the topmost bed of the Permian crinoidal limestones beneath the microbialite.

Fig. 6. Location of South China Block (1), Iran (2) and Turkey (3) in low latitude Tethys Ocean (based on palaegeographic map from Golonka, 2002), with interpreted ocean currents and sites of upwelling (u) and sinking (s) of ocean water (Kidder and Worsley, 2004). See text for discussion. 


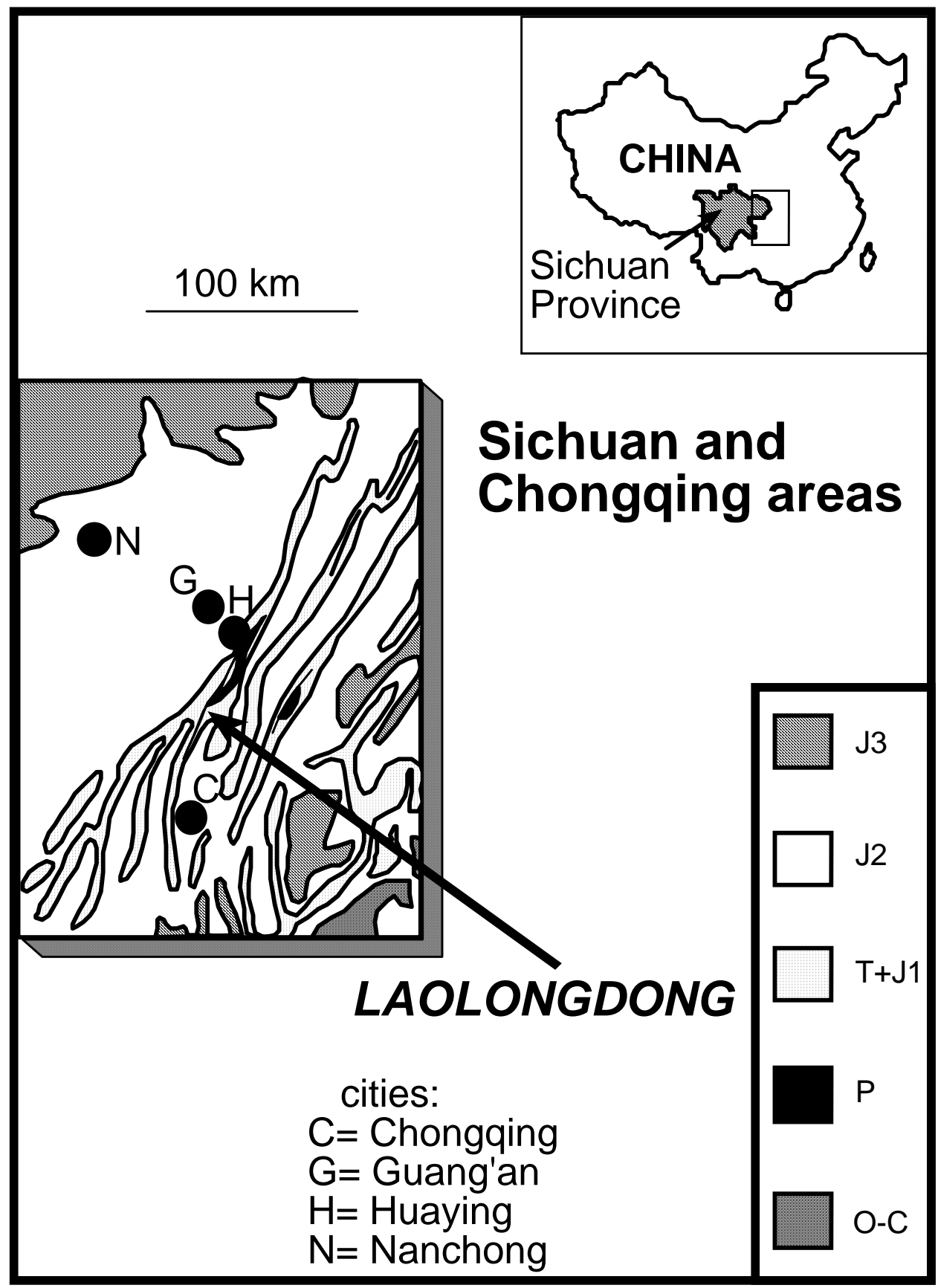

Figure 1. 
X. Mu, S. Kershaw, Y. Li, L. Guo, Y. Qi, A. Reynolds "High-resolution carbon isotope changes in the Permian-Triassic boundary interval, Chongqing, South China; implications for control and growth of earliest Triassic microbialites” J. Asian Earth Sciences (2008) Archive Version. Definitive version available at www.sciencedirect.com

Figure 2 A

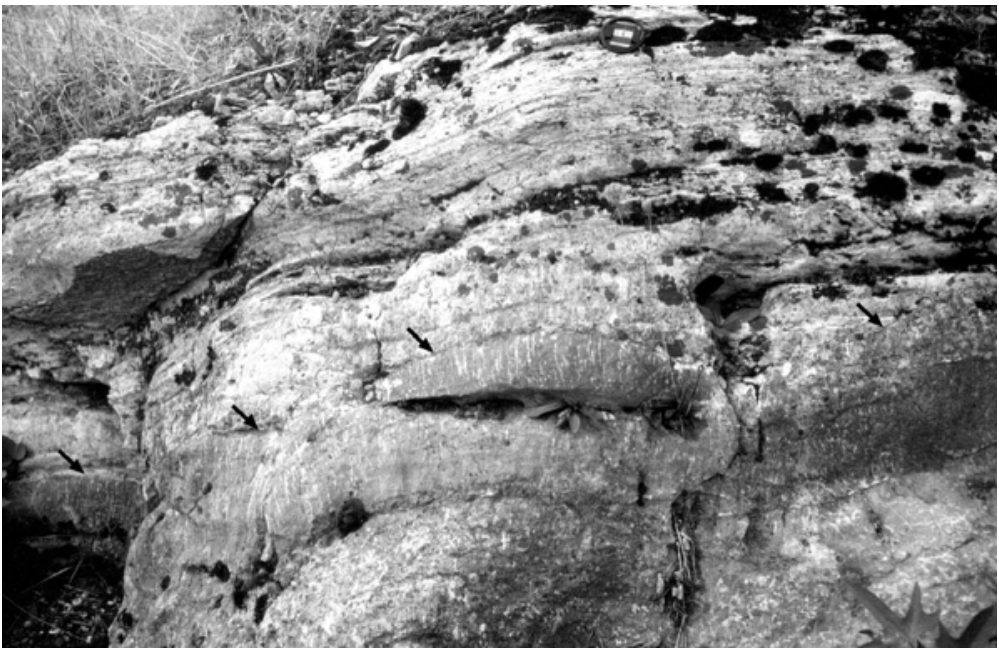

Figure 2 B

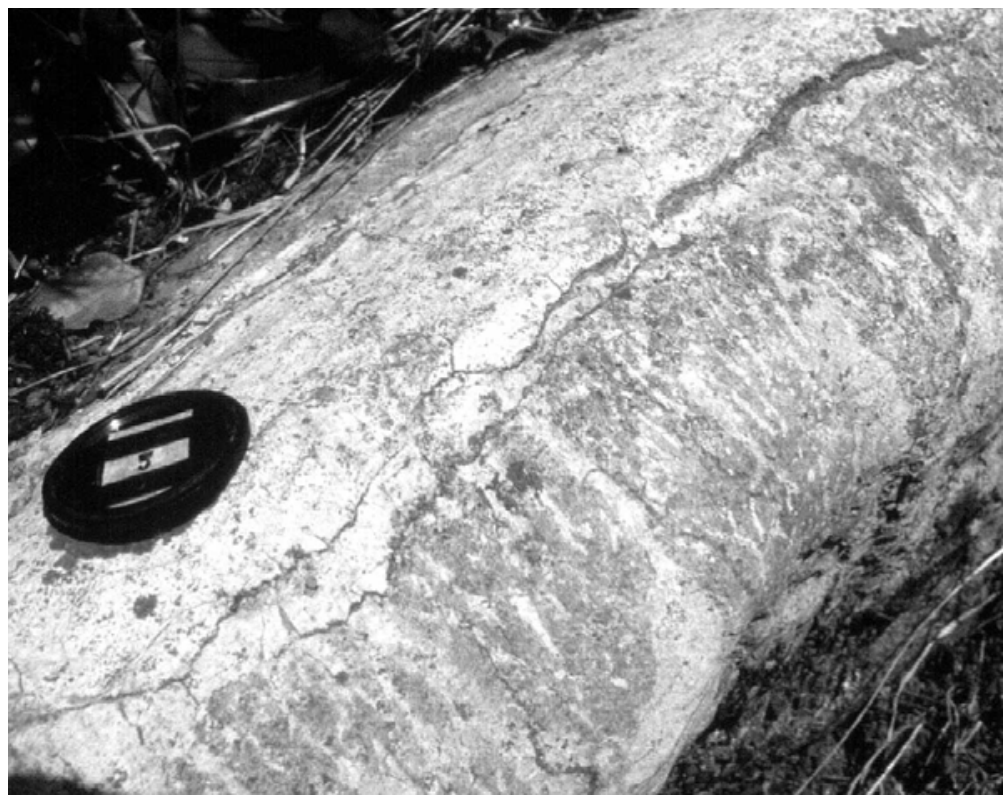


X. Mu, S. Kershaw, Y. Li, L. Guo, Y. Qi, A. Reynolds "High-resolution carbon isotope changes in the Permian-Triassic boundary interval, Chongqing, South China; implications for control and growth of earliest Triassic microbialites” J. Asian Earth Sciences (2008) Archive Version. Definitive version available at www.sciencedirect.com
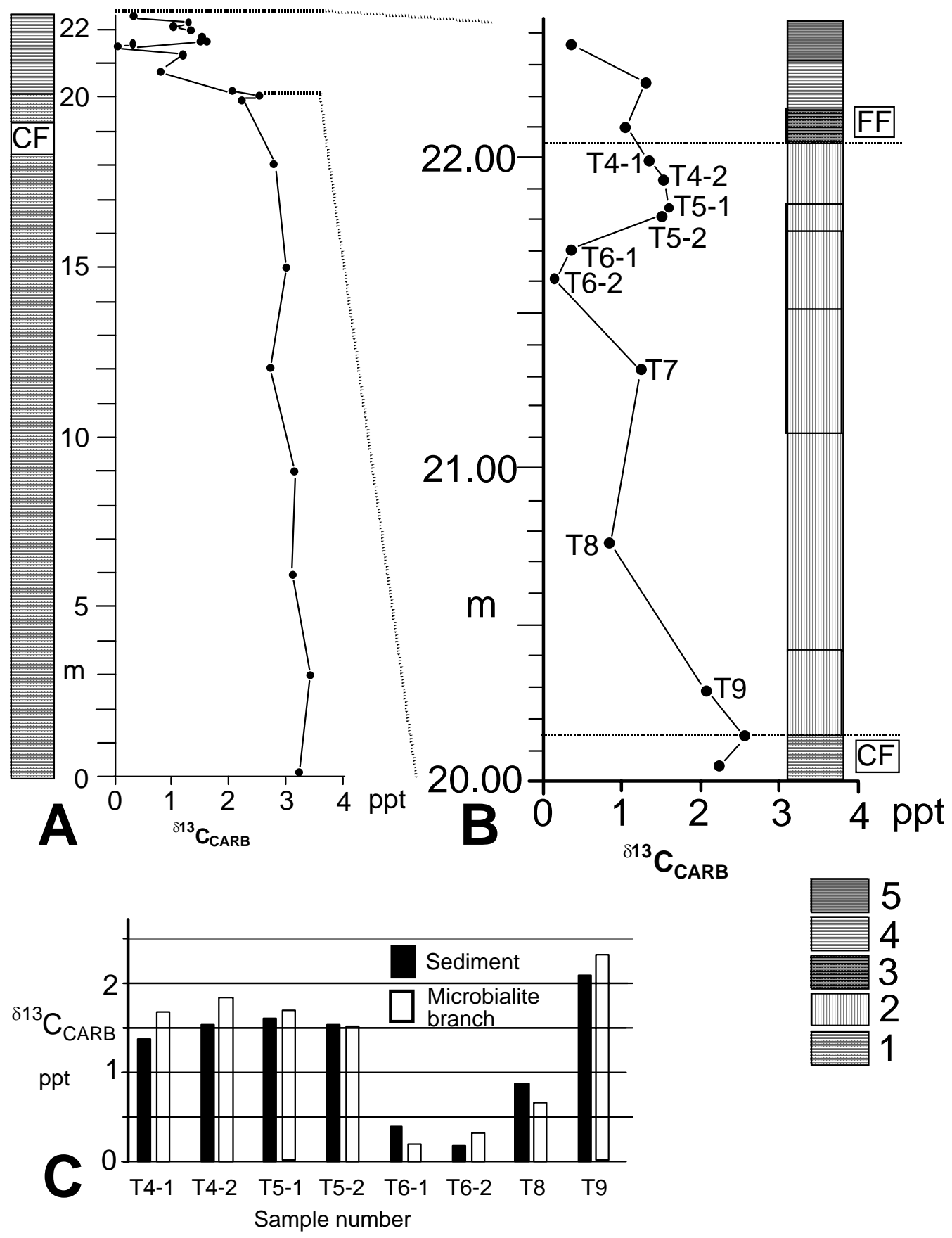

5

4

3

2

Figure 3 
X. Mu, S. Kershaw, Y. Li, L. Guo, Y. Qi, A. Reynolds "High-resolution carbon isotope changes in the Permian-Triassic boundary interval, Chongqing, South China; implications for control and growth of earliest Triassic microbialites” J. Asian Earth Sciences (2008) Archive Version. Definitive version available at www.sciencedirect.com

\begin{tabular}{|c|c|c|c|c|}
\hline $\begin{array}{c}\text { Sample No. } \\
\text { IRef. No. }\end{array}$ & $\begin{array}{c}\text { Height } \\
\text { cm }\end{array}$ & $\begin{array}{c}\text { 13Ccarb } \\
\text { PDB }\end{array}$ & $\begin{array}{c}\text { 18Ocarb } \\
\text { PDB }\end{array}$ & Notes \\
\hline T1/201042 & 2240.000 & 0.390 & -6.535 & \\
\hline T2/201044 & 2226.000 & 1.314 & -6.829 & \\
\hline T3/201046 & 2211.000 & 1.075 & -8.490 & 1 \\
\hline T4--1-S/201047 & 2199.000 & 1.377 & -9.034 & 2 \\
\hline T4--2-S/201049 & 2193.000 & 1.534 & -7.192 & \\
\hline T5-1-S/201052 & 2184.000 & 1.602 & -6.891 & \\
\hline T5-2-S/201054 & 2181.000 & 1.527 & -6.753 & \\
\hline T6-1-S/201056 & 2170.000 & 0.396 & -6.746 & \\
\hline T6-2-S/201058 & 2161.000 & 0.181 & -6.860 & \\
\hline T7-S/201061 & 2132.000 & 1.244 & -7.170 & \\
\hline T8-S/201063 & 2077.000 & 0.866 & -6.796 & \\
\hline T9-S/201065 & 2028.000 & 2.094 & -6.944 & \\
\hline TD/201045 & 2015.000 & 2.621 & -6.831 & 3 \\
\hline T10/201067 & 2005.000 & 2.326 & -6.896 & \\
\hline T36/201078 & 1800.000 & 2.791 & -6.771 & \\
\hline T35/201076 & 1500.000 & 2.923 & -6.357 & \\
\hline T34/201075 & 1200.000 & 2.755 & -6.405 & \\
\hline T33/201074 & 900.000 & 3.148 & -5.826 & \\
\hline T32/201072 & 600.000 & 3.106 & -5.881 & \\
\hline T31/201071 & 300.000 & 3.420 & -5.699 & \\
\hline T30/201068 & 0.000 & 3.229 & -5.978 & \\
\hline
\end{tabular}

SAMPLES comparing sediment and microbialite branch; S=sec

\begin{tabular}{|c|l|l|l|l|}
\hline$T 4-1-S / 201047$ & & 1.377 & -9.034 & \\
\hline$T 4-1-B / 201048$ & & 1.667 & -7.284 & \\
\hline$T 4-2-S / 201049$ & & 1.534 & -7.192 & \\
\hline$T 4-2-B / 201050$ & & 1.832 & -6.887 & \\
\hline$T 5-1-S / 201052$ & & 1.602 & -6.891 & \\
\hline$T 5-1-B / 201053$ & & 1.687 & -6.808 & \\
\hline$T 5-2-S / 201054$ & & 1.527 & -6.753 & \\
\hline$T 5-2-B / 201055$ & & 1.525 & -7.010 & \\
\hline$T 6-1-S / 201056$ & & 0.396 & -6.746 & \\
\hline$T 6-1-B / 201057$ & & 0.202 & -7.009 & \\
\hline$T 6-2-S / 201058$ & & 0.181 & -6.860 & \\
\hline$T 6-2-B / 201059$ & & 0.313 & -6.955 & \\
\hline$T 8-S / 201063$ & & 0.866 & -6.796 & \\
\hline$T 8-B / 201064$ & & 0.652 & -6.334 & \\
\hline$T 9-S / 201065$ & & 2.094 & -6.944 & \\
\hline$T 9-B / 201066$ & & 2.302 & -7.262 & \\
\hline
\end{tabular}

Figure 4 
X. Mu, S. Kershaw, Y. Li, L. Guo, Y. Qi, A. Reynolds "High-resolution carbon isotope changes in the Permian-Triassic boundary interval, Chongqing, South China; implications for control and growth of earliest Triassic microbialites” J. Asian Earth Sciences (2008)

Archive Version. Definitive version available at www.sciencedirect.com
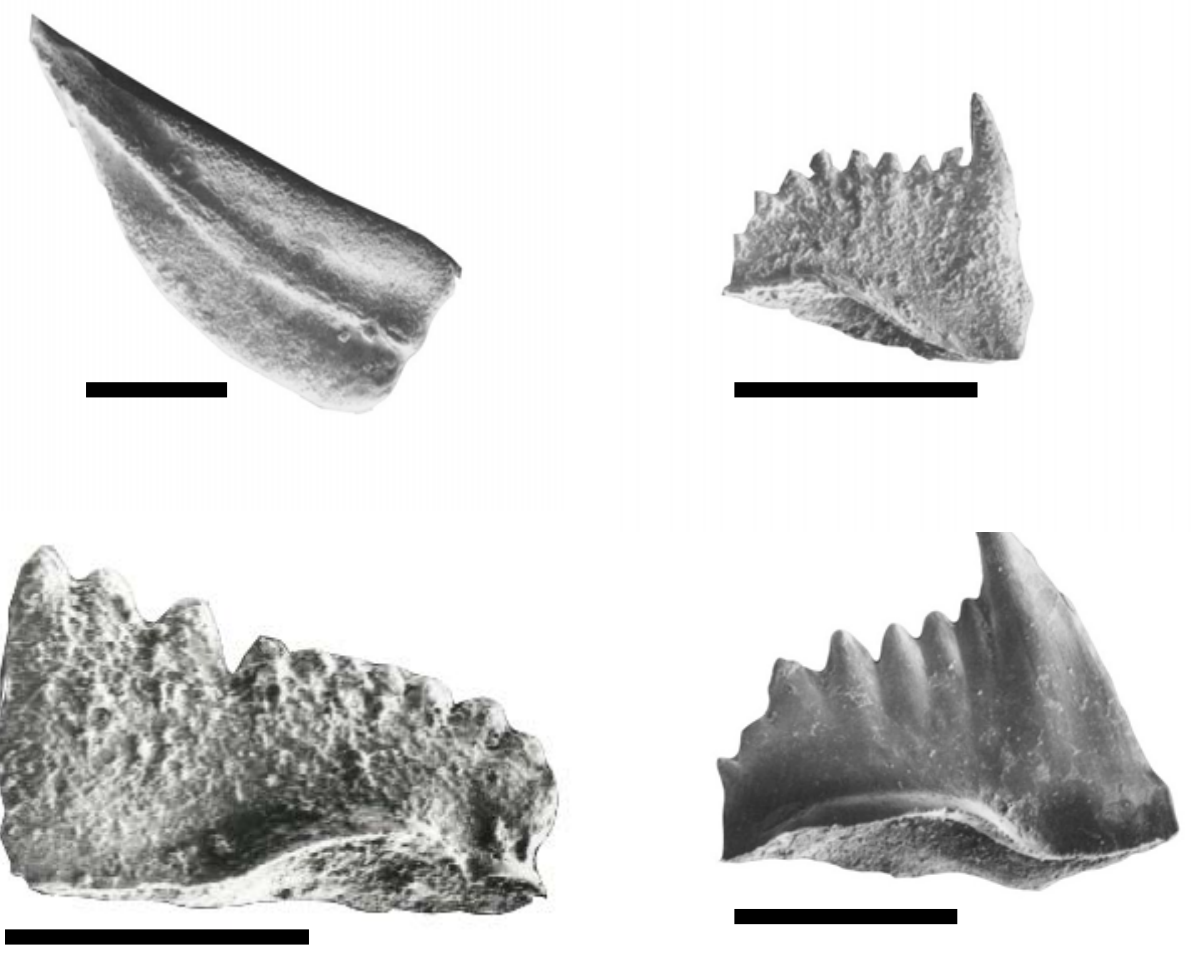

Figure 5 
X. Mu, S. Kershaw, Y. Li, L. Guo, Y. Qi, A. Reynolds "High-resolution carbon isotope changes in the Permian-Triassic boundary interval, Chongqing, South China; implications for control and growth of earliest Triassic microbialites” J. Asian Earth Sciences (2008) Archive Version. Definitive version available at www.sciencedirect.com

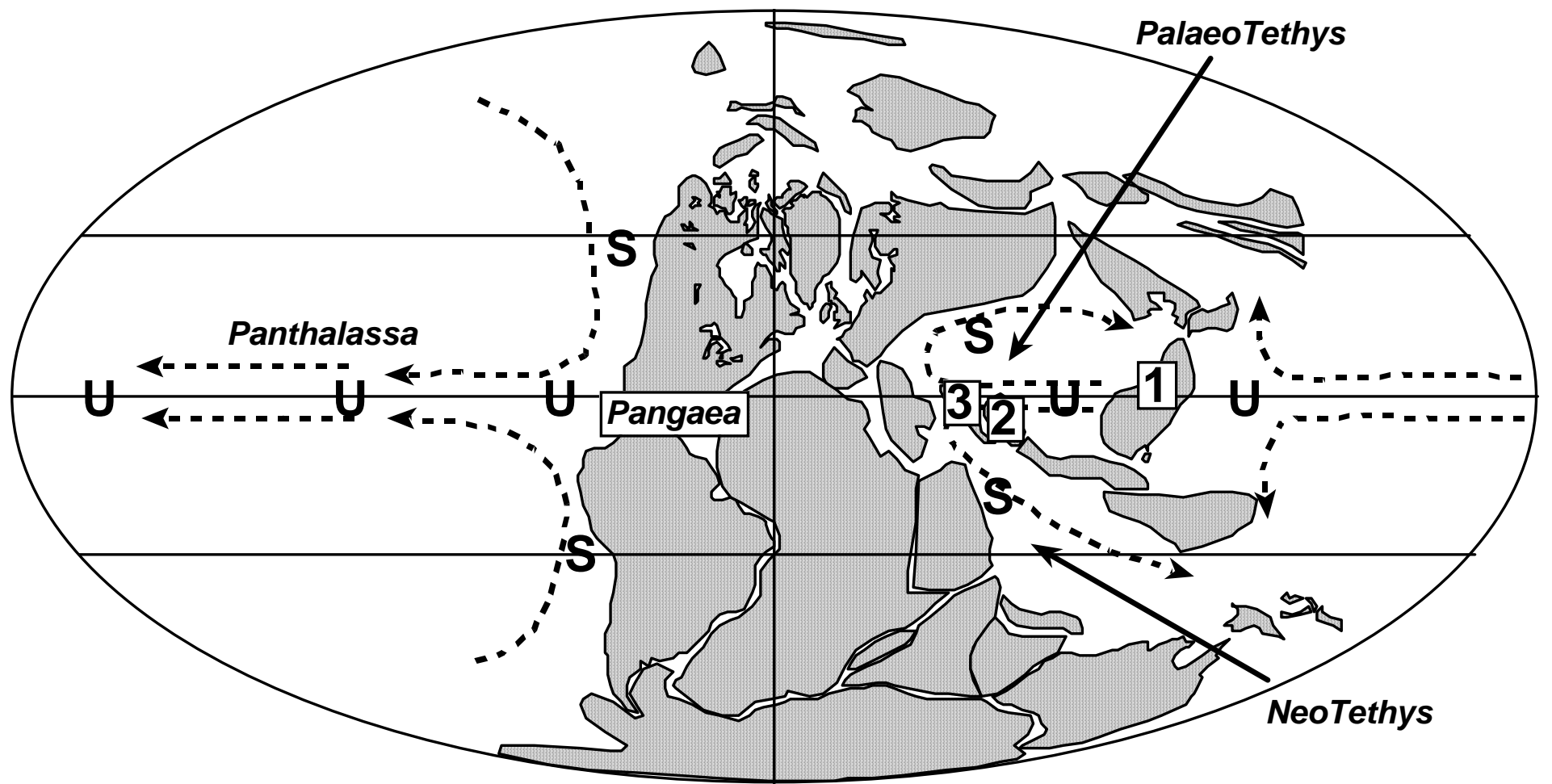

Figure 6 